\title{
Opinions and perceptions of physical education students about value education
}

\author{
Eyüp Bozkurt* and Mikail Tel \\ Faculty of Education, Firat University, Turkey. \\ Received 20 May, 2016; Accepted 18 August, 2016
}

\begin{abstract}
Values make people live together and have common grounds. Value education, which starts in the family are, shaped by the environment that children live in. After children start school, they being to learn value education. School inculcates the values adopted by the community to the children. The most important executor of value is the teacher. If teachers have good values and are well informed about values, they can teach children in a better way. Children see their teachers as a role model and they behave like them. To students, teachers are excellent and qualified people. This study was performed to obtain the viewpoint of Physical Education Department students studying value education. This research is screening model and thus descriptive. The sample of the research is composed of 158 Physical Education Department students. In the result of the research, the students stated that they have enough information about values education. Teachers should be the role model in value education, and it should be taught as a course in universities
\end{abstract}

Key words: Education of values, physical education, physical education and values.

\section{INTRODUCTION}

The purpose of education and teaching is to raise people that can adapt to the society and who have quality that others can trust. In the globalized world, it is necessary to move round the world, and grown individuals should be able to live anywhere in the world. "In the globalization process and its resultant economic, social, technological changes and development, the major goal is to create individuals who can cooperate with others; citizens who are active, participative, responsible and outgoing " (Narin, 2007). Based on this, the most important factor should be giving of values in the upbringing of individuals. According to Çengelci (2010), values are the principle, standard and thoughts that symbolize desired qualities such as good, right, beauty that are guide to human behaviours. According to Halstead and Taylor (1996), values are the standard of principle, belief, idea and living that create our personal integrity; guide our assessments related to various beliefs and actions; affect our decisions on any issue; and shape our behaviours. If education priority is to prepare individuals in the society to have values, this purpose can be reached. Generally, our aims, expectations and beliefs constitute values (Raths et al., 1987). "Value education covers all of the activities applied in order to raise people with good behaviours

*Corresponding author. E-mail: ebozkurt@firat.edu.tr.

Authors agree that this article remain permanently open access under the terms of the Creative Commons Attribution License 4.0 International License 
such as understanding of other persons, tolerating them and developing social sensibility" (Ekşi and Katılmış, 2011).

The peace of mind of a given people who live in a society is directly proportional to the importance they given value education. "In parallel with ignoring or preserving values in individuals, either values will get lost with time or they will continue to the next generation" (Akbaba, 2003). Unfortunately, the third page news lately in our country has shown that we lose our values day by day. According to Fitcher (1990), as a sociological mean, values are the means used to measure the importance of other socio-cultural elements and aims, behaviour models of group or society. "Today, while all things are in the rapid and periodic change, Turkish values have also taken this condition being a very critical situation" (Yel and Aladağ, 2012). Our attitudes and behaviours towards values have lost their sensitivity compared to the past. "Values affect the attitudes and behaviours of people; they play a significant role in determining their attitudes and behaviours" (Dilmaç, 2012).

Although learning starts from our mothers' womb, people cannot take the natural values that they have got. "Values that individuals have are developed in life because they are not natal features" (Gömleksiz and Cüro, 2011). People create their own sense of values based on the environment they live in and create their attitude of life accordingly. The family has a great impact in the formation of personality; thus family provides a particular value to children. After children start school, it replaces many works of the family. The first learning experiences that occur in the house provide support to learning attempts in the school, and it raises the chances of teachers to becoming successful in classroom applications" (Çelenk, 2003). Students consider their teachers as their idol by seeing them as a role model. Due to the nature and structure of physical education lessons, students are enchanted by physical education teachers. The physical education teachers who children see as role models show required model behaviour to children and provide attribution to their development.

Although education and training are the responsibility of teachers and the school, the family has more function and role to play in this matter than anyone else, because all kinds of education and training are acquired first from the family. First values are learnt from the family, and other values are acquired from institutions like school, peer group and society (Sapasağlam and Ömeroğlu, 2016). The values that are learnt from family are transferred by children to their social lives and school environment. Since education is continuous, values education continues in schools. Every course actually has national and global values in its own curriculum. The duty of teachers is to convey these completely and make sure that they are permanent in children. Values education constitutes a part of curriculum in different educational environments worldwide (Singh, 2011).

Values education can be considered as part of education. In this respect, all teachers must play their role and contribute their quota, because value education constitutes a significant part of life and this education should start at early age. It deals with many aspects such as honesty, mercy, loyalty, respect, trust and responsibility along with the character education of early childhood (Mei-Ju et al., 2014). Children who acquire these values at early age will become more healthy individuals. They will not experience difficulties in solving problems at their later age. Character education must meet the needs of early adolescence (8th and 9th grades) to strengthen social skills. Also, it will serve as a complementary factor for adolescents to embrace character education (Cheung and Lee, 2010). Youths should have skills in future, such as the ability to solve conflicts. Today's problems and living conditions are getting more difficult and require having sound personalities. The youths are increasingly under the impact of bullying, social problems, violence, disrespect and the world around them, while their parents and teachers are affected by new problems and pressures (Tillman, 2000). In order not to be overwhelmed by problems and to stay strong, behavioral and value education should be taken care of starting from early childhood.

Game is very important in all stages of education for children. A child is in his game age when he first starts school. Therefore, it is not true to convey the curriculum only to a child who is just in his game age. While game has such importance in the lives of children, physical education teachers and game classes are also of great importance. It is a big mistake to see game class as a means of keeping children busy and making use of spare time. Studies show that children learn a subject more easily and permanently when such subject is combined with game. Accordingly, physical education teachers should avoid seeing game as a sports activity only. Big contributions can be made for the development of children with activities and values that will be included in the game at every opportunity. Value education represents an ancient tradition known best for its focus on education as a moral enterprise, and hence requiring that it should be characterized by ethically positive relationships and discourse (Lovat, 2011).

\section{METHODOLOGY}

\section{The purpose of the research}

This study aims to determine the opinions of physical education department students about value education.

\section{The research model}

This research that determines the opinions of physical education 
Table 1. Distributions of the personal information of the physical education students in the research.

\begin{tabular}{llcc}
\hline Variable & & Frequency (f) & Percentage \\
\hline \multirow{2}{*}{ Gender } & Male & 73 & 46.2 \\
& Female & 85 & 53.8 \\
\multirow{3}{*}{ Place of birth } & Village & 22 & 13.9 \\
& County Town & 37 & 23,4 \\
& City Centre & 99 & 62.7 \\
General Academic grade point averages & 2.50 and under & 28 & 17.9 \\
& $2.51-3.00$ & 52 & 33.3 \\
& $3.01-4.00$ & 76 & 48.7 \\
\hline
\end{tabular}

teacher candidates about value education of values is a screening model. Screening models are the research approaches used to describe a situation that exists in the past or currently (Karasar, 2009).

\section{The universe and sample}

Physical education teaching department students constitute the universe of the research. 158 physical education teaching department students studying in Fırat University Physical Education and Sports College constitute the sample of the research.

\section{Data collection and analysis}

The data were obtained applying the survey scale developed by Merter and Bozkurt (2014). Statistical package for social sciences (SPSS) is used for the analysis of data. "Arithmetic mean", "percentage" and "frequency" were used for the analysis of data obtained by the researcher. Students' opinions were tested to describe their response level from the variables based on the demographic data with the t-test independent groups.

\section{RESULTS}

\section{Results and comments concerning the personal information of physical education students}

Table 1 shows the personal information of the physical education students used in this study.

\section{Distributions of the opinions of the physical education students about value education}

In Table 2, the physical education teacher candidates "agree" with the following items thus:

"I have enough information about value education" (=3.85), "I have enough information about the methods and techniques used in value education" $(=3.61)$, "The determinant of value education is the family " $(=3.94)$, "The cooperation of school and family should be included in value education " $(=4.00)$, "Value education should be seen as schools' main duty" (=3.71), "Value education is important for academic achievement" (=4.02), "Teachers should be the role model in value education" $(=3.94)$, "The most important issue is value education " $(=3.81)$, "The media has a major impact on value education" (=3.79), "Value education should be done within the framework of certain plan and program in the schools" $(=3.94)$, "Teachers should be models of value education " (=3.98), "Value education requires the cooperation of all units in the school" (=3.93), "Many of the social problems originate from insufficient implementation of value education " $(=3.89)$, "Value education should be programmed and performed in parallel to today's technological developments" (=3.91), "Democratic class environment should primarily be created for value education " $(=3.86)$, "Value education course should be included in the training faculties of undergraduate programs" (3.84), "Value education remains in the background according to the academic achievements of the schools" (=3.81), " The activities related to value education can be exercised to students in the physical education lesson." (=3.80), "Value education can be taught better with games in gym class." (=3.78), "I think that in schools, value education is not beneficial " $(=3.60)$, "I am not good at value education" (=3.50). The students "partially agree" with the item, "sufficient study is done on value education in universities" (=3.31).

The earlier mentioned findings show that the physical education teachers stated that value education is not taught efficiently at schools. Also, prospective teachers said that graduate courses should be available in relevant universities on value education. Value education can be offered in a more effective and efficient way with the cooperation of the school, family and social environment. Therefore, teachers should be informed and have command of values at schools.

According to gender variable, comparison of opinions of physical education students who participated in the research

In Table 3, there is significant distinction in the analysis 
Table 2. The opinions of physical education students concerning the education of values.

\begin{tabular}{|c|c|c|c|c|c|c|c|c|c|}
\hline \multirow{2}{*}{$\mathbf{M}$} & \multirow{2}{*}{ Opinions for education of values } & \multirow{2}{*}{ N. } & \multicolumn{5}{|c|}{ Participation rate (\%) } & \multirow{2}{*}{$\bar{X}$} & \multirow{2}{*}{ ss } \\
\hline & & & TA & IA & PA & DA & NA & & \\
\hline 1 & I have enough information about value education & 158 & 3.8 & 0.6 & 27.2 & 43.0 & 25.3 & 3.85 & 0.93 \\
\hline 2 & $\begin{array}{l}\text { Sufficient education on value education is given in } \\
\text { universities }\end{array}$ & 157 & 9.5 & 7.6 & 37.3 & 31.6 & 13.3 & 3.31 & 1.10 \\
\hline 3 & $\begin{array}{l}\text { I have enough information about the methods and } \\
\text { techniques used in value education }\end{array}$ & 155 & 3.8 & 7.6 & 26.6 & 44.9 & 15.2 & 3.61 & 0.96 \\
\hline 4 & The determinant of value education is the family & 155 & 1.9 & 5.1 & 19.0 & 43.0 & 29.1 & 3.94 & 0.93 \\
\hline 5 & $\begin{array}{l}\text { The cooperation of school and family is needed in } \\
\text { value education }\end{array}$ & 155 & 1.3 & 3.8 & 16.5 & 47.5 & 27.8 & 4.00 & 0.85 \\
\hline 6 & $\begin{array}{l}\text { Value education should be seen as the schools' } \\
\text { main duty }\end{array}$ & 153 & 2.5 & 10.1 & 22.8 & 41.8 & 22.2 & 3.71 & 1.00 \\
\hline 7 & $\begin{array}{l}\text { Value education of values is important for academic } \\
\text { achievement }\end{array}$ & 157 & 2.5 & 5.1 & 15.8 & 38.6 & 36.1 & 4.02 & 0.98 \\
\hline 8 & $\begin{array}{l}\text { Teachers should be the sample persons in value } \\
\text { education }\end{array}$ & 155 & 3.2 & 6.3 & 13.3 & 45.6 & 30.4 & 3.94 & 0.99 \\
\hline 9 & The most important issue is to value education & 156 & 1.9 & 9.5 & 22.2 & 34.8 & 28.5 & 3.81 & 1.03 \\
\hline 10 & $\begin{array}{l}\text { The media has a major impact on the value } \\
\text { education }\end{array}$ & 153 & 3.8 & 7.6 & 19.6 & 39.9 & 25.9 & 3.79 & 1.04 \\
\hline 11 & $\begin{array}{l}\text { Value education should be done within the } \\
\text { framework of certain plan and program in schools }\end{array}$ & 153 & 1.3 & 4.4 & 20.3 & 46.2 & 27.2 & 3.94 & 0.87 \\
\hline 12 & Teachers should be model in value education & 157 & 3.2 & 3.8 & 18.4 & 38.0 & 33.5 & 3.98 & 0.99 \\
\hline 13 & $\begin{array}{l}\text { Value education requires the cooperation of all units } \\
\text { in school }\end{array}$ & 153 & 2.5 & 4.4 & 18.4 & 46.2 & 28.5 & 3.93 & 0.93 \\
\hline 14 & $\begin{array}{l}\text { Many of social problems have been originated from } \\
\text { insufficient implementation of value education }\end{array}$ & 158 & 1.9 & 5.7 & 25.9 & 32.9 & 32.9 & 3.89 & 0.99 \\
\hline 15 & $\begin{array}{l}\text { Value education should be programmed and } \\
\text { performed in parallel to today's technological } \\
\text { developments }\end{array}$ & 157 & 2.5 & 4.4 & 17.7 & 48.7 & 25.9 & 3.91 & 0.91 \\
\hline 16 & $\begin{array}{l}\text { Democratic class environment should primarily be } \\
\text { created for value education }\end{array}$ & 157 & 1.9 & 8.9 & 17.1 & 42.4 & 27,2 & 3.86 & 0.99 \\
\hline 17 & $\begin{array}{l}\text { The lesson about value education should be } \\
\text { included in the training faculties of undergraduate } \\
\text { programs }\end{array}$ & 154 & 1.3 & 7.6 & 17.7 & 46.8 & 22.2 & 3.84 & 0.91 \\
\hline 18 & $\begin{array}{l}\text { Value education remains in the background } \\
\text { according to the academic achievements in schools }\end{array}$ & 151 & 1.9 & 7.6 & 22.8 & 43.0 & 24.7 & 3.81 & 0.95 \\
\hline 19 & $\begin{array}{l}\text { The activities related to value education can be } \\
\text { exercised to students in physical education lesson }\end{array}$ & 158 & 1.3 & 9.5 & 20.3 & 44.3 & 23.4 & 3.80 & 0.95 \\
\hline 20 & $\begin{array}{l}\text { Value education can be taught better with games in } \\
\text { gym class }\end{array}$ & 156 & 3.2 & 5.1 & 27.2 & 36.7 & 25.9 & 3.78 & 0.99 \\
\hline 21 & $\begin{array}{l}\text { I think that in schools, value education is not } \\
\text { beneficial }\end{array}$ & 155 & 4.4 & 10.1 & 27.2 & 34.8 & 22.2 & 3.60 & 1.08 \\
\hline 22 & I know much about value education & 156 & 5.1 & 12.0 & 27.2 & 39.2 & 16.5 & 3.50 & 1.06 \\
\hline
\end{tabular}

TA: I Totally Agree, IA: I Agree, PA: Partially Agree, DA: I Disagree, NA: I never agree. 
Table 3. According to gender variable, comparison of opinions of physical education students who participated in the research.

\begin{tabular}{lcccccccc}
\hline \multirow{2}{*}{ MN } & \multicolumn{5}{c}{ Female } & \multicolumn{5}{c}{ Male } & \multirow{2}{*}{$\mathbf{t}$} & p \\
\cline { 2 - 7 } & $\mathbf{n}$ & $\overline{\mathbf{X}}$ & $\mathbf{s s}$ & $\mathbf{n}$ & $\overline{\mathbf{X}}$ & $\mathbf{s s}$ & & \\
\hline 2 & 72 & 3.20 & 1.22 & 85 & 3.41 & 0.99 & 1.152 & 0.251 \\
13 & 73 & 3.86 & 1.03 & 85 & 4.00 & 0.84 & 0.917 & 0.360 \\
17 & 70 & 3.81 & 1.06 & 81 & 3.87 & 0.76 & 0.416 & 0.678 \\
\hline
\end{tabular}

${ }^{*} \mathrm{P}<0.05$.

Table 4.According to Academic Average, Comparison of Opinions of Physical Education Students who participated in the research.

\begin{tabular}{cccccccccl}
\hline \multirow{2}{*}{ MN } & \multicolumn{2}{c}{$\mathbf{2 . 5 0}$ and under (a) } & \multicolumn{2}{c}{$\mathbf{2 . 5 1 - 3 . 0 0}(\mathbf{b})$} & \multicolumn{2}{c}{$\mathbf{3 . 0 1 - 4 . 0 0}(\mathbf{c})$} & \multicolumn{2}{c}{ Variance } & \multirow{2}{*}{ Difference groups (Scheffe) } \\
\cline { 2 - 9 } & $\overline{\mathrm{X}}$ & $\mathbf{S}$ & $\overline{\mathrm{X}}$ & $\mathbf{S}$ & $\overline{\mathrm{X}}$ & $\mathbf{S}$ & $\mathbf{F}$ & $\mathbf{p}$ & \\
\hline 5 & 28 & 0.92 & 50 & 1.00 & 73 & 0.65 & 4.935 & 0.008 & a-c, b-c \\
8 & 27 & 1.07 & 52 & 1.13 & 75 & 0.78 & 3.339 & 0.038 & b-c \\
\hline
\end{tabular}

${ }^{*} \mathrm{P}<0.05$.

result based on gender variable on, "There is sufficient study on value education given in universities" $(\mathrm{t}=1,152$; $p<0.05)$. This opinion is accepted by the male teacher candidates $(=3.41)$ more than the female teacher candidates $(=3.20)$. There is significant distinction in the analysis result based on gender variable on "Value education requires the cooperation of all the units in school" $(t=0,917 ; p<0.05)$. This opinion is accepted by the male teacher candidates $(=4.00)$ more than the female teacher candidates $(=3.86)$.

In Table 3, there is significant distinction in the analysis result based on gender variable on, "Value education should be included in the training faculties of undergraduate programs" $(t=0,416 ; p<0.05)$. This opinion is accepted by the male teacher candidates $(=3.87)$ more than the female teacher candidates $(=3.81)$.

The findings shown above indicate that female teachers think that values education is not offered enough in universities. However, results show that male teachers state that such education is offered much in universities but think that a value education course must be made available in universities. From the results, it can be concluded that male candidate teachers are not sensitive, and do not care about value education.

\section{According to academic average, comparison of opinions of physical education students who participated in the research}

In the paired comparison, the scheffe test was applied primarily. In Table 4, there is significant distinction in the variance analysis based on academic average variables on "The cooperation of school and family should be included in value education" $(F=4,935 ; p<.05)$. It has been shown that the people whose academic average is 2.50 and under $(=0.92)$ accepted more than the people whose academic average is between 3.01 to $4.00(=0.65)$ that "Teachers should be the role models of value education." It has been shown that the people whose academic average is 2.51 to $3.00(=1.00)$ accepted more than the people whose academic average is between 3.01 to $4.00(=0.65)$ that "Teachers should be the sample persons in value education." There is significant distinction in the variance analysis result based on academic average variables on, "Teachers should be the sample persons of value education" $(F=3,339 ; p<0.05)$. It has been shown that the people whose academic average is 2.51 to $3.00(=41.13)$ accepted more than the people whose academic average is between 3.01 to 4.00 $(=0.78)$ that "Teachers should be the sample persons in value education."

\section{According to birthplace variable, comparison of opinions of physical education students who participated in the research}

In the paired comparison, the scheffe test was applied primarily. In Table 5, there is significant distinction in the variance analysis result based on birth place variable on, "The most important issue is value education" $(F=3,384$; $\mathrm{p}<0.05)$. It has been shown that the people whose birthplace is town $(=1.15)$ accepted more than the people whose birth place is village $(=0.94)$ and city centre $(=0.97)$ that "The most important issue is value education." 
Table 5. According to birthplace variable, comparison of opinions of physical education students who participated in the research.

\begin{tabular}{cccccccccc}
\hline \multirow{2}{*}{ MN } & \multicolumn{4}{c}{ Village (a) } & \multicolumn{4}{c}{ County town (b) } & \multicolumn{2}{c}{ City centre (c) } & \multicolumn{2}{c}{ Variance } & Difference groups \\
\cline { 2 - 10 } & $\overline{\mathbf{X}}$ & $\mathbf{S}$ & $\overline{\mathrm{X}}$ & $\mathbf{S}$ & $\overline{\mathrm{X}}$ & $\mathbf{S}$ & $\mathbf{F}$ & $\mathbf{p}$ & (Scheffe) \\
\hline 9 & 21 & 0.94 & 36 & 1.15 & 96 & 0.97 & 3.384 & 0.037 & a-b, b-c \\
10 & 21 & 1.04 & 35 & 1.09 & 97 & 1.00 & 3.351 & 0.038 & a-b, b-c \\
16 & 22 & 0.95 & 35 & 1.19 & 97 & 0.88 & 3.474 & 0.034 & a-b, b-c \\
\hline
\end{tabular}

${ }^{*} \mathrm{P}<0.05$.

In Table 5, there is significant distinction in the variance analysis result based on birth place variable on, "The media has a major impact on value education" ( $F=3,351$; $p<0.05)$. It has been shown that the people whose birthplace is town $(=1.09)$ accepted more than the people whose birth place is village $(=1.04)$ and city $(=1.00)$ that "The media has a major impact on value education."

In Table 5, there is significant distinction in the variance analysis result based on birth place variable on, "Democratic class environment should primarily be created for value education" $(F=3,474 ; p<0.05)$. It has been shown that the people whose birthplace is county town $(=1.19)$ accepted more than the people whose birth place is village $(=0.95)$ and city $(=0.88)$ that "Democratic class environment should primarily be created for value education."

Findings in Table 5 show that candidate teachers who were born in a town stated that the media has more influence on value education, compared to those who were born in a city and village. In fact, media is the most important factor in values education. With the development of technology, people are now acting and growing under the influence of media. The fact that such influence is accepted by candidates who were born in town is an indicator of that.

\section{CONCLUSIONS AND RECOMMENDATIONS}

In the study, the participants stated that they have enough information about value education. The researchers stated that the school should see value education as its main duty. They stated that teachers should be the role models in value education. The female researchers have argued that "Value education is not sufficiently taught in the universities" more than male researchers. The male teacher candidates have accepted that "value education lesson should be included in the universities" more than female teacher candidates. The participants whose academic average is high have accepted that "Teachers should be the sample person in value" more than the other participants whose academic average is low. The male teachers have accepted that "Value education requires the cooperation of all units in the school." more than female teachers.

\section{SUGGESTIONS}

1. Information on how to teach value education should be included in all of the academic programs.

2. Informative studies on the importance and role of teachers should be done in value education.

3 . Excluding the education of national values strategy, value education should be planned and organised.

4. Researchers can do studies on the role of school in value education. Researchers can do studies on value education with games.

\section{Conflict of interests}

The authors have not declared any conflict of interests.

\section{REFERENCES}

Akbaba AS (2003). Eğitim Yönetimi ve Değerler. Değerler Eğitimi Dergisi 1(1):7-17.

Cheung CK, Lee TY (2010). Improving social competence through character education. Evaluation and program planning, 33(3), 255263.

Çelenk S (2003). Okul Başarısının Ön Koşulu: Okul Aile Dayanışması, İlköğretim-Online 2 (2):28-34.

Çengelci T (2010). Illköğretim Beşinci Sınıf Sosyal Bilgiler Dersinde Değerler Eğitiminin Gerçekleştirilmesine İlişkin Bir Durum Çalışması. Doktora Tezi, Anadolu Üniversitesi, Eskişehir.

Dilmaç B (2012). İnsanca Değerler Eğitimi. Pegem Akademi, Ankara

Ekşi H, Katilmiş A (2011). Karakter Eğitimi El Kitabı.. Nobel Yayın Dağıtım, Ankara

Fitcher J (1990). What is sociologu? (Translation; Nilgün Çelebi). Konya: Selçuk Üniversitesi Yayınları, No: 75.

Gömleksiz MN, Cüro E (2011). Sosyal Bilgiler Dersinde Yer Alan Değerlere İlişkin Öğrenci Tutumlarının Değerlendirilmesi. Uluslararası Insani Bilimleri Dergisi 8(1):95-134.

Halstead JM, Taylor MJ (1996). Values in education and education in values. London: The Falmer Press

Karasar N (2009). Bilimsel Araştırma Yöntemi, Nobel Dağıtım, Ankara.

Lovat T (2011). Values education and holistic learning: Updated research perspectives. Int. J. Educ. Res. 50(3):148-152.

Mei-Ju C, Chen-Hsin Y, Pin-Chen H (2014). The beauty of character education on preschool children's parent-child relationship. ProcediaSoc. Behav. Sci. 143:527-533.

Merter F, Bozkurt E (2014). Sınıf Öğretmeni Bölümü Öğrencilerinin Değerler Eğitimine IIlişkin Görüşleri. Turkish Studies İnternational Periodical For the Languages Literature and History of Turkish or Turkic Volume: 9/5 Spring.

Narin D (2007). İlköğretim Hayat Bilgisi Dersi Öğretim Programı'nın 
Vatandaşlık Bilgi, Beceri ve Değerlerini Kazandırmasına İlişkin Öğretmen Görüşleri. Yüksek Lisans Tezi, Anadolu Üniversitesi, Eskişehir.

Raths EL, Harmin M, Simon BS (1987). Selections from Values and Teaching.Carbone, F. P. (Ed.). Value Theory and Education (pages: 198-214). Robert E. Krieger Publishing Company Malabar, Florida.

Singh A (2011). Evaluating the Impacts of Value Education: Some Case Studies. Int. J. Educ. Plann. Admin. 1:1-8.
Tillman D, Colomina PQ (2000). Living values activities for children ages 8-14. Health Communications.

Yel S, Aladağ S (2012). Sosyal Bilgilerde Değerlerin Eğitimi, Safran, M. (Ed.) Sosyal Bilgiler Öğretimi, Pegem Akademi, Ankara. 